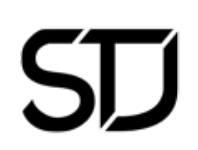

\title{
Preaching the Trinity today
}

\author{
Johannes P. Deetlefs \\ University of the Free State \\ Bloemfontein, South Africa \\ johannesdeetlefs@gmail.com
}

\begin{abstract}
While the twentieth century has witnessed renewed interest in the doctrine of the Trinity, in their daily lives Christians are mostly unaffected by it. The reason for this lack of knowledge and the negligence of this vital Christian doctrine could be blamed partly on a lack of preaching the doctrine of the Trinity. Considering the fact that the doctrine of the Trinity is the distinguishing doctrine of the Christian faith, such neglect in the homiletical ministry of the church is truly lamentable. This article is aimed at discussing some of the possible reasons for this regrettable situation and offering some guidelines for preaching the Trinity. Considering the practical implications of this foundational Christian doctrine for the ecclesial community, as well as for society at large, the church can no longer afford the neglect of the preaching of the Trinity. While I am writing from within the South African context, the issues raised here are relevant to the church internationally.
\end{abstract}

\section{Keywords}

Christian life; preaching; relational; trinitarian; Trinity; ethical

\section{Introduction}

The twentieth century has witnessed a renewed appreciation of, and interest in, the doctrine of the Trinity among scholars from various Christian backgrounds and traditions. The flood of literature on this fundamental doctrine of the Christian Faith has become overwhelming, and the renewed interest has even been described as a renaissance (Cunningham 1998:19), and an obsession (Olson \& Hall 2002:95). Surprisingly, this enthusiasm for the doctrine of the Trinity is not reflected in the daily lives of Christians, who for most of the time seem to be ignorant of this central doctrine and the practical implications it has for personal as well as church life. While on Sundays Christians worship the Trinity in song and confession, for the 
rest of the week most of them live their lives as mere monotheists (Olson \& Hall 2002:54). Letham's (2004:5) words carry an element of truth when he laments: "Today most Western Christians are practical modalists." Leupp (1996:16) voices the same concern and finds this lack of trinitarian consciousness among church members regrettable. Vincie (2010:182) refers to Rahner's lament that if we dispense with the doctrine of the Trinity theological discourse would hardly be affected, and goes on to argue that the same would probably apply to Christian praxis. For many people, both Christian and non-Christian, the Trinity "remains esoteric and irrelevant" (Cunningham 1998:ix). White (1998:16) probably summarises the situation the best:

Most Christian people, while remembering the term 'Trinity', have forgotten the central place the doctrine is to hold in the Christian life. It is rarely the topic of sermons and Bible studies, rarely the object of adoration and worship - at least worship in truth, which is what the Lord Jesus said the Father desires (Jn 4:23). Instead, the doctrine is misunderstood as well as ignored. It is so misunderstood that a majority of Christians, when asked, give incorrect and at times downright heretical definitions of the Trinity. For others, it is ignored in such a way that even among those who correctly understand the doctrine, it does not hold the place it should in the proclamation of the Gospel message, nor in the life of the individual believer in prayer, worship and service.

If it is true that the Christian life is life in the Trinity (Downey 2000:44), how should this paradox be explained? Why is so little of the excitement and renewed interest in the doctrine of the Trinity that is evident in scholarly discourse visible within church communities? One reason for this discrepancy, and an important one I believe, is the lack of preaching this foundational doctrine of the Christian Faith. For various reasons (some of which I will discuss below) there is very little evidence of preaching the Trinity. The aim of this article is to investigate the state of preaching the Trinity, consider the reasons for lack of trinitarian preaching, and suggest some guidelines for fruitful preaching of this fundamental doctrine of Christianity. While I am writing from within the South African context, I believe that the issues raised here are relevant to all traditions of the church internationally. 


\section{Trinitarian consciousness}

Trinitarian faith confesses the one God, not as a solitary single person, but as three "persons" - Father, Son and Spirit - who together comprise the one true God (Plantinga, Thompson \& Lundberg 2010:131). God is a being in communion (Gunton 1997:9). "The Trinity is the free, just, and loving communion of three distinct co-equal divine persons, a communion that also embraces both humanity and the world" (Bitrus 2018:1). Venter (2014:2) suggests that from the unity and plurality of God as Father, Son and Spirit flow two critically important insights: the relationality of being, and that this relationality constitutes identity. "God is Father, Son and Spirit, and Father, Son and Spirit are uniquely that because of their respective relationships" (Venter 2014:2).

The emphasis on relationality as characteristic of the divine life opens up new possibilities for, and a better understanding of, trinitarian theology. The development of a social Trinity resulted in the location of the personhood of the Trinity in the three hypostases rather than the one substance. Social trinitarians argue that the proper locus of divine personhood is the diversity within God - the three hypostases. However, one should be careful not to regard "person" in its modern sense as an individual substance. The trinitarian persons are unique and exist only in their relationships with one another (Moltmann 1991:171-172). Zizioulas (1985:88) distinguishes between person and individual and emphasises the relational character of personhood. Applied to the persons of the Trinity, this means that each person exists in the light of the others and receives the fullness of eternal life from the others (Moltmann 1991:173-174). The unity of the triune God "lies in personal diversity, a real communion of these distinct persons" and is "communicable, integrative, and open, such that their fellowship includes humanity, history, and the whole of creation" (Bitrus 2018:161). The doctrine of the Trinity acknowledges the uniqueness of each of the persons while the unity of the one God is upheld.

\section{Preaching the Trinity}

How often is the doctrine of the Trinity the central message in preaching? Suggit (1993:vii) suggests that preaching of God as triune is rare and lays the following charge: "Even on Trinity Sunday, however, we hear little in 
preaching about the meaning of God as Trinity." Hunt (2005:197f.) argues that at least on Trinity Sunday the Trinity should be preached, and she expresses concern about the neglect thereof. Burrows (2002:16) correctly argues that "the goal of preaching is to lead people to participate ever more consciously in the life of the Trinity and draw out the consequences of that new life in service of the Kingdom." A study conducted by Shuster (1999:357-381) suggests that very few sermons explicitly treat the doctrine of the Trinity.

\subsection{Reasons for lack of preaching the Trinity}

If the Trinity lies at the heart of Christian Faith and is essential for Christian living, why do we not hear more sermons on the Trinity? What could cause such neglect of the Trinity in preaching? Shuster (1999:360-376) suggests the following possible reasons:

- Resistance of both preachers and church members against the preaching of dogma, which they regard as dry and boring with little practical value for life. The perception exists in some circles that dogma is divisive and leads to separation, and that it is therefore best to avoid preaching dogma.

- The mystery of the being of God scares preachers, and they avoid preaching on a difficult topic such as the Trinity. When it comes to the Trinity, it requires diligent study and careful formulation if one is to escape the danger of proclaiming heresy. Faced with the mystery of the Trinity, one is reminded of the inadequacy of one's own intellect, as well as the poverty of human language, to describe such a supreme and holy mystery. Hunt (2005:198) recalls the case of a priest who, after he completed an intensive study of the Trinity, was advised by his teacher to avoid speaking of the Trinity for more than three minutes out of fear that he may proclaim false doctrine.

- Another obstacle to preaching the Trinity is the entertainment orientated spirit prevalent within societies today. People are more interested in quick-fix solutions to their daily problems than in the objective truths of the Christian Faith. Who cares if God is one or three persons? All that is important, is what God can do for us to meet our daily needs. Serious preaching that challenges the intellect (as preaching the Trinity would certainly do!) leaves people cold. 
- The spirit of relativism in today's communities, where dogma is considered dangerous for the unity among people from different faiths, resulted in a discomfort with dogmatic preaching, causing ministers to be reluctant to preach topics such as the Trinity.

In light of the above, Shuster (1999:372) pleads for a "rebirth of doctrinal preaching" and especially difficult doctrines such as the doctrine of the Trinity. The need for preaching the Trinity in order to set the Christian understanding of this essential doctrine on a sure foundation should be recognised, and the challenge to rectify this unsatisfactory situation should be met with the necessary seriousness.

\subsection{Importance of preaching the Trinity}

Edgar (2004:20) expresses the conviction of most Christian theologians when he emphasises that the Trinity is "the distinctive Christian doctrine" and therefore essential for Christian discipleship and living. The doctrine of the Trinity has the potential to enrich our lives and the way in which we relate to God and live out our Christian faith (Tyson 2005:90).

Given that we belief that we are created in the image of God, the doctrine of the Trinity throws light on our life, on what we are created and called to be, on our sharing with each other and in the divine life, the communion of love that is God. In other words, the doctrine of the Trinity is not just about who God is, but who we are and what we are called to be and become. It concerns all of human reality - its joys and sorrows, its hopes and its fears, its fragility and its nobility, and its ultimate destiny (Hunt 2005:183).

I concur with the above and would argue that one can hardly overemphasise the importance of preaching the Trinity. It is in the liturgy, of which preaching is an essential element, that the triune nature of God as Father, Son, and Spirit should be most clearly reflected (Kärkkäinen 2015:60).

\section{Guidelines for preaching the Trinity}

To preach the Trinity is no easy task. Yet, it is important that it should be done. The question is, how? If not done with the necessary care, such preaching may only add to the confusion about the doctrine that already 
exists among church members. One will have to guard against preaching that describes the Trinity in cold and abstract terms which have very little relevance to the lives of the congregation. What is needed is a "particular kind of trinitarian theology" which links the concept of God with "God's actions for us and our salvation" (Vincie 2010:182). The sermon needs to emphasise the practical relevance that the Trinity has for Christian living through "themes of relationship, communion and communication, and belonging" (Lord 2012:37). With this in mind, I dare to offer the following suggestions for preaching the Trinity.

\subsection{Human limitation}

First and foremost, it is necessary that we realise that there are things that our human minds simply fail to comprehend. When one contemplates the complex being whom we call God, we are faced with a mystery that is just so overwhelming that one can hardly find the words to describe it (Heyns 1978:51). There are certain limitations to human understanding, and "we must expect that our frail, sinful, and limited human capacity to reason will be severely tested when trying to accommodate itself to the divine reality" (McGrath 2006:18-19).

Does this mean that we are doomed to silence? Certainly not! God has taken the initiative to disclose Godself, and therefore we have the obligation to speak about God and to faithfully witness to God's glory and merciful love for creation. "If God has taken the initiative in self-disclosure, and we have received the gift of God's self-unveiling in our experience, then we are required to speak both to and about the Giver. The faithfulness and truth with which God has declared God's own self calls out for us to witness faithfully to God" (Fiddes 2000:30). It is, therefore, incumbent upon us to proclaim the glory of the triune God in our preaching, aware of our own inability and dependence on the Holy Spirit to enlighten our minds.

\subsection{Balance needed}

It is important that the message of the Trinity be shared in a way that will have practical value for the congregation. The focus should not be on abstract ideas, but on "the central aspects of God's life for us and within us" (LaCugna 1986:214). Abstract technical and philosophical language should best be avoided (Kärkkäinen 2015:60) and the starting point should be the 
economic Trinity rather than the immanent Trinity (Lord 2012:15). The preacher's task is not to lecture doctrine, but to remind the congregation of their faith in the trinitarian God - Father, Son and Holy Spirit. "The sermon is not the time to hear a lecture" (Lord 2012:15). Preaching the Trinity should assist the congregation to grasp the fact that God is personal and relational (LaCugna 1986:224). By focusing on "the economy of salvation" our preaching can address the "real concerns of the people of God who are eager for a word of healing, liberation, and hope" (Vincie 2010:187).

However, the sermon must move from the economic Trinity to the immanent Trinity. Shuster (1999:373) correctly cautions that

... in preaching, one not focusses so exclusively on aspects of Christian faith as experienced that one altogether lose track of the traditional assumption that there is a truth, however imperfectly grasped and expressed, that lies behind the experiences. With respect to the Trinity, that means not completely losing track of the immanent Trinity in favour of the economic Trinity (while granting that most of one's exposition will probably deal with the latter).

There should be a balance between the abstract facts about the immanent Trinity and the practical relevance of the doctrine. The congregation should at least understand the biblical teaching regarding the Trinity. "One of the defining insights in contemporary trinitarian theology is that we ascend from concrete history of salvation and God's overall creative, preserving, redeeming, and perfecting works, on to the knowledge of the Father, Son, and Spirit" (Kärkkäinen 2015:60).

What about the use of analogies for the Trinity? Here one should tread carefully. Analogies may become a minefield that can lead to misunderstanding and, if unchecked, even downright heresy. Lord (2012:16) cautions that "analogies for the Trinity are best avoided" since these usually fail as true reflections of the triune God and more often than not lead to confusion, resulting in the errors of modalism, tritheism, subordinationism, or some other distorted views of the Trinity.

\subsection{Practical implications of the Trinity}

In what ways can the doctrine of the Trinity enhance the well-being and practical living of the church? In other words, in which way would faith in 
the triune God impact the practical lives of believers? Leupp (1996:25-26) argues that practical Christian living is dependent on trinitarian terms, and claims that " $\mathrm{t}] \mathrm{he}$ Trinity is an eminently practical doctrine, not for the sake of practicality alone, but because the Triune God is the living God who invites all creation into the abundance of his life." In this he echoes LaCugna (1991:378-379) who emphasises that the Trinity has the potential to enhance understand of the demands of the gospel in terms of relationships and the glory of God. "Both theology and praxis would be quite different if the doctrine of the Trinity were allowed to serve at the centre of Christian faith" (LaCugna 1991:379).

Love

No other Christian doctrine gives such meaning to the words "God is love" (1 Jn. 4:8) than the doctrine of the Trinity. "When Christians say, "God is love”, we are speaking of the Trinity" (Butin 2001:77). God's being as love has been emphasised by the church father Augustine who claimed that " $\mathrm{t}$ ] he Father is Lover, the Son the Beloved, and the Spirit the mutual Love that connects the two" (Kärkkäinen 2007:46). Since "God is a community of persons bonded together in love” (Wadell 2011:345), God is not dependent on creation in order to be love. As Schwöbel (1998:327) aptly states: "God is love eternally in the perfection of the divine being ... God is personal and relational as the God who is triune love."

Since God, within God's triune being, is love, God is free to love the world (1 Jn 4:9-11). "God's very being is relational because at the heart of God is not solitude and isolation, but a trinity of persons united in perfectly intimate love" (Wadell 2011:345). God's love is aimed at creation and God's concern is mainly the well-being of human beings (Kärkkäinen 2015:61). Humanity's deepest need for love and acceptance is satisfied by God who shows God's love for humanity in the death of God's beloved Son (cf. Jn. 3:16; Rom. 5:8). In the love which God has for us the human person comes into contact with Godself, since God is love (Schwöbel 1998:311). Schwöbel (1998:325) correctly states:

Only if the disclosure of God's love is a real self-disclosure it would be possible to say that God is love and only if the indwelling of the Spirit is a real presence of God could we say that in the Spirit we relate to God as God is in himself. 
That the triune God is love has ethical implications for humanity who has been created in the image of this triune God (Gn. 1:26-27). Since God loves us, we must love one another (1 Jn. 4:11, 19). Being created in the image of God, we are obliged to, in the same way as God, love and reach out to creation (Vincie 2010:185). Being the object of God's love, humans are exhorted to love others as persons, created in God's image, who are also loved by God. "Since we are all loved by God, each one of us can be a giver and a recipient of love" (Schwöbel 1998:309).

The Church should be an icon of the Trinity through relationships and communities who display "affection, trust, faithfulness, and care" (Wadell 2011:345). God enables us to love our neighbour "because God's love has been poured into our hearts through the Holy Spirit that has been given to us" (Rom. 5:5). Schwöbel (1998:312) points out the connection between our love for God and others, God's love for us and God's being as love. In the words of Wadell (2011:346):

In a world riven by hostilities and divisions, the Church becomes not a place of refuge and retreat, but a new polity, a distinctive, visible, concrete society modeled not on an anthropology of domination, but on the politics of truthfulness and peace made possible by the life, death, and resurrection of Jesus. Committed to the new way of life envisioned in Jesus' proclamation of the reign of God, Christians constitute a community where people take care of one another, are patient with one another, and seek the well-being of one another. In their pledge to live according to the disciplines and practices of the reign of God, they show the joy and freedom that come from renouncing retribution and embracing reconciliation and peace instead. It is this commitment to follow the new way of life begun by Christ that makes the Church a true instrument of salvation for the world.

\section{God's presence}

There is a deep desire among humans, especially in times of trouble or suffering, for the assurance that God is present within their lives. While the concern and support of others are appreciated, people "also seek comfort from their God" (Pembroke 2006:97). With the current worldwide coronavirus pandemic, the question of the presence of God has become an 
urgent matter for many. Godzieba (2018:273) expresses this human desire when he asks: "how is the ineffable God available to us within our embodied, time-bound life?" It is in God's revelation of Godself as a communion of love, and in the actions of the Son through the Spirit that humans become participants of God's household and experience the presence of God (cf. Gal 2:4-7). The Father sent the Son for the redemption of the world through his death and resurrection, and through the actions of the Holy Spirit “people become God's dwelling and his home" (Moltmann 1981:213). The greeting "The grace of the Lord Jesus Christ, the love of God, and the communion of the Holy Spirit be with all of you." (2 Cor 13:13) holds the promise of the ongoing presence of the triune God in the lives of believers. "The assembly is sent forth, renewed in spirit by deepening of trinitarian communion, to serve the world which God loves, saves, and keeps in being" (Schaefer 2010:148). Believers who love the Lord are assured of the indwelling presence of the Father, the Son and the Holy Spirit (Jn 14:23; 1 Cor 3:16-17) and may continuously enjoy communion with the triune God (1 Jn. 1:3).

However, this is not always the experience of persons, especially when they are going through difficult times in their lives. Often, overwhelmed by their own vulnerability, they feel alone and lost. "Where is God?", they ask. This sense of God's absence is "an experience of grasping for God during a time of need and not finding Him" (Giardino 2019:233). In circumstances like these, it is important that they become aware that God's presence and absence are closely related. God's presence in the world is "a hidden, patient and suffering presence ... acting in persuasive and sacrificial love rather than coercion" (Fiddes 2004:43).

God is present by fulfilling our innermost desires for love and meaning, and yet disturbingly absent by shattering our expectations and escaping our attempts at a complete synthesis or a definite understanding, exceeding our limited categories of description and understanding (Godzieba 2018:310).

In a mysterious way God is able, even in God's absence, to address us and extend a divine invitation to fellowship with the triune God, in which we may experience the presence of God through our participation in the shared life of the Trinity (Giardino 2019:234). 
Our encounters with God often "occur as part of the ordinariness of everyday life" - help from a stranger; undeserved forgiveness; an overwhelming liturgical experience; the choice of justice and peace over violence, a kind gesture of encouragement, and so on. Awareness that God is the source of these encounters helps one to experience the presence and love of God in a tangible way (Godzieba 2018:310-311).

The Trinity "opens us up to participation, to experience the rhythm of divine self-giving that makes possible particular performances of discipleship" (Godzieba 2018:314). As disciples of Christ, led by the power of the Spirit, we are exhorted to model the actions of Christ (Lk. 10:37). When we, following the example of Christ, reach out in love to the marginalised, those alienated from the community, and those who suffer, not only do we help them to encounter the presence of the triune God, but we share in their experience of the nearness and love of God. In the words of Godzieba (2018:309), "we experience the mystery of God's infinite love when we personally incarnate its particular effects in our time-bound everyday lives."

\section{Hospitality}

"To speak of God is to speak of giving, gift, and hospitality" (Kärkkäinen 2014:310). The one God who eternally exists as three persons, Father, Son and Holy Spirit, is lovingly drawing us "into this divine life, into this true home. The image is of the Holy Trinity as our home, our safe place, our space of belonging" (Lord 2012:37). The triune God makes space for humans to be taken up into the divine life and to have fellowship with the Father and the Son (1 Jn 1:3). In this way the name of the triune God becomes a safe haven for believers (cf. Prov 18:10), creating the space where believers experience the presence of the living God, hope for the marginalised, and a welcome that invites the creation of communion (Kärkkäinen 2014:311).

While the triune God is welcoming all to enter into the fellowship of the community of God, the limitations to the hospitality of God must be acknowledged. God's open invitation is simultaneously a call to discipleship - a life that is faithful to Christ. "Those who share in the life of the community of God are called to live in conformity to Christ. There is both unbounded and bounded openness in the hospitality of God" (Pembroke 2006:31). 
Hospitality as a Christian virtue flows forth from the hospitality of the triune God who is both Giver and Gift (Kärkkäinen 2014:310). As those who have accepted God's gracious invitation to participate in the communion of the Divine, "we must now extend an invitation to those outside" (Pembroke, 2006:34). Humanity comprises different cultures and ethnic groups, where each person is a unique individual with his or her own personality, temperament and characteristics. It is important that we accept and welcome the other in their difference. Fiddes (2000:25-26) points to the balance that must be maintained between similarity and diversity. We should guard against, on the one hand, accepting only one personality type as normative and, on the other hand, just ignoring the differences between the other and ourselves as if they do not exist. This may be experienced as an insult by the other.

Vosloo's (2004:69) remark in this regard is meaningful: "A Christian ethic of hospitality challenges the notion of an enclosed identity in which the aim is to protect my/our identity by insulating me or us from what is different and other." He cautions against a "romantic openness" toward the other who is different from us, since that would negate the concrete identity of the other. Instead, what is needed is a "certain kind of identity - an identity open to the other and otherness" (Vosloo 2004:71). He (2004:87) further emphasises that the Trinity is "not a self-enclosed identity but ... a self-giving and other-receiving identity" that challenges our inclination toward closing ourselves to the other who is different from us. In the words of Moltmann (2000:122): "Those who love are not in themselves but in others; those who are loved give others free space to live in them." Here it is important to heed Pembroke's (2006:21) timely warning against, on the one hand providing too little space, and on the other hand, allowing too much space. The first usually results in "failure to respect otherness", while the latter makes true communion impossible.

This unity in diversity should be characteristic of the Christian community. In the church people from different races, cultures, economic and social status within society are united in Christ. This unity should not push aside the diversity but welcome and appreciate it (cf. Col 3:12). LaCugna (1991:403) points out that " $\mathrm{t}]$ he unity of all believers in the Spirit does not vitiate genuine differences among persons nor exclude diversity of rite, dogma, and custom. Indeed, difference is a precondition to true 
communion, inasmuch as persons by definition are utterly unique and unrepeatable." Churches that, through isolating themselves from others, and do not acknowledge and reflect this diversity within unity, cannot truly reflect the image of the triune God. "Jesus sought out the outcast, welcomed the stranger, and brought good news to the oppressed" (Butin 2001:107). It is not through judging the world, but by showing "the possibility of lasting intimacy, friendship, and love in a community that refuses to let enmity and vengeance prevail" (Wadell 2011:347) that the church becomes a true witness of the kingdom of God.

\section{Koinonia}

God is a community who "exists in the intimate intercommunion of Father, Son, and Holy Spirit" (Butin 2001:91). In this communion all are equal. No one is more than or above the others. The members of the Trinity are dependent on one another for their existence. Volf (1998:407) is adamant that in this "community of perfect love between persons who share all divine attributes a hierarchy is unintelligible." It is within this perichoretic community of love that God is one. Moltmann (2000:123) explains: "The unity of the triune God is the personal community of Father, Son, and Holy Spirit. The divine persons have everything in common, except their personal characteristics."

It is within this communion that "the divine persons are giving each other themselves and the divine life in selfless love" (Moltmann 2000:115). This communion is expressed in the Greek word perichoresis.

The divine persons exist in their mutual relationships for one another and through their reciprocal indwelling in one another. By virtue of their perichoresis the divine persons exist so intimately with one another, for one another, and in one another that they constitute a single, unique, and complete unity by themselves (Moltmann 2000:117).

The loving Father sends the Son and the Spirit in order to create fellowship with humans (Kärkkäinen 2015:64). Humans are created for communion with the triune God and with one another. When we live in true communion with each other we reflect the triune being of God. "God intends the divine koinonia to be reflected in human koinonia" (Butin 2001:91). LaCugna (1991:382) correctly states: "Entering into divine life therefore is impossible 
unless we also enter into a life of love and communion with others." She convincingly argues that both God and humans "were meant to exist as persons in communion in a common household, living as persons from and for others, not persons in isolation or withdrawal or self-centeredness" (LaCugna 1991:383).

The koinonia for which God has created humanity has two dimensions, a vertical and a horizontal, and they cannot be separated, as is clear from 1 John 1:3, “... we declare to you what we have seen and heard so that you also may have fellowship with us; and truly our fellowship is with the Father and with his Son Jesus Christ." Butin (2001:92) points out that humans, "created as persons in the divine image ... are created for interpersonal relationship with the interpersonal God: The Trinity."

The church, as the body of Christ, is where this communion should be visible and experienced. LaCugna (1991:402) calls the church an icon and sacrament of the Trinity, by which she means that the church "presents in concrete form the ineffable and invisible mystery of triune life." Members of the church should accept and serve one another in a community of love which reflects the triune reality. "The nature of the church should manifest the nature of God” (LaCugna 1991:403).

As the persons of the Trinity depend on each other for their existence (the Father cannot be Father without the Son, and the Son can only be the Son of the Father), members of Christ's body, the church, are dependent on one another to develop their full potential as human beings. "But when the Trinity is the pattern for our human communion in the church, interdependence multiplies our ability to fulfil God's purposes" (Butin 2001:108). In such a community, where people are treated with respect and dignity and no-one forces their opinions onto others, "decisions are arrived at by consensus rather than by mandate" (Schaefer 2010:152). This interdependence cultivates empathy among members and a willingness to accept responsibility for each other's well-being. Authentic communion calls for self-emptying, where the individuality and personal freedom of the other is respected (Pembroke 2006:43). Through their acceptance of responsibility for each other, church members become willing to serve one another with all the gifts that they receive from God. LaCugna (1991:384) emphasises this important aspect of being a Christian: 
Our relationship to others, which is indistinguishable from our relationship to Jesus Christ, determines whether we are or are not finally incorporated into God's household. The reign of God, prepared from the foundation of the world, is present when we feed the hungry, give drink to the thirsty, welcome the stranger, clothe the naked, attend to the sick, or visit the prisoner, for in doing this to another, we do it to Jesus himself.

The result is a community where the image of the Divine - albeit "a tarnished image" - is mirrored, reflecting "the mutual indwelling in love that is the Trinity" (Pembroke 2006:43).

\section{Worship}

Christian worship is not so much a matter of personal taste or style, something that we do toward God, but it is "God's relationship with us, and our relationship with God, that is the primary concern of worship" (Butin 2001:97). Through the Spirit, God lifts believers up into the communion of the Father and the Son so that they can enjoy fellowship with the triune God (Edgar 2004:23). Worship is to be totally focussed on God!

The church's worship is based on who God is and what God has done for us. The Father sent his Son for our redemption, and Father and Son sent the Spirit to be within the church and to renew the whole of creation (cf. Gal $4: 4-7)$. God's actions toward us flow "from the Father through the Son by the Holy Spirit" and our reaction to God's grace is worship "by the Holy Spirit through Christ to the Father" (Letham 2004:413-414).

In Trinitarian worship, God the Father extends divine grace, love, goodness, comfort, presence, challenge, and motivation to us through God's Word and Spirit. We respond to God's initiative as God the Spirit opens our hearts to God's grace, presence, and ministry, placing before us again all that God has done for us in the Son (Butin 2001:98).

Downey (2000:46) reminds us that it is through Christian faith and life, as well as the "doxology of the human heart praising God in the name of Father, Son, and Spirit that we receive, acknowledge, and respond to the mystery of the Trinity." 
An essential aspect of worship is prayer. Through prayer believers are mysteriously connected to all believers everywhere in the communion of the holy (Butin 2001:104). "Christian prayer is Trinitarian: to the Father, through the Son, in the Spirit" (Downey 2000:41). Prayer raises us "into communion with the persons of the Holy Trinity" (Letham 2004:423). It is worthwhile to take note of Butin's (2001:106) remark in this regard: "When trinitarian worship and prayer are the vital wellspring of a congregation's life, the community of faith begins to experience foretastes of the overflow of God's own interpersonal koinonia." In this communion, the church knows that its prayer, "offered through Christ, its high priest and mediator and imbued with the mind of Christ thanks to the Spirit (1 Cor 2:16; Phil 2:5), is always heard" (Schaefer 2010:154).

\section{Conclusion}

The lack of preaching the Trinity is a cause for concern. This doctrine is just too important, and its practical relevance too meaningful for the way in which Christians live their lives, to be neglected in the homiletical ministry to the church. Lack of preaching the Trinity leaves members of the Body of Christ ignorant of the means of living as images of the triune God in a world of inequality, strive and injustice. Recognition of the ability of trinitarian faith to provide "a vision for our lives, relationships, and practices" (Vincie 2010:187) underlines the importance of preaching the Trinity, and hopefully will stir church leaders to make a conscious effort to include the doctrine of the Trinity to their preaching and teaching programmes.

\section{Bibliography}

Bitrus, I.S. 2018. Community and Trinity in Africa. London \& New York: Routledge.

Burrows, W.R. 2002. Preaching and immersion in trinitarian life. The Living Pulpit, January-March:16-17.

Butin, P.W. 2001. The Trinity. Louisville: Geneva Press. 
Cunningham, D.S. 1998. These Three are One: The practice of trinitarian theology. Oxford: Blackwell Publishers.

Downey, M. 2000. Altogether Gift: A Trinitarian Spirituality. Maryknoll, NY: Orbis.

Edgar, B. 2004. The Message of the Trinity: Life in God. Leicester: InterVarsity Press.

Fiddes, P.S. 2000. Participating in God: A Pastoral Doctrine of the Trinity. Louisville: Westminster/John Knox.

-2004. The quest for a place which is "not-a-place": The hiddenness of God and the presence of God, in O. Davies \& D. Turner (eds.). Silence and the Word: Negative theology and Incarnation. Cambridge: Cambridge University Press. 35-60.

Giardino, J. 2019. Divine absence as divine presence. Journal for Cultural and Religious Theory, 18(2):224-235.

Godzieba, A.J. 2018. A Theology of the absence and presence of God. Collegeville: Liturgical Press Academic.

Gunton, C.E. 1997. The promise of Trinitarian theology (2nd ed.). Edinburgh: T\&T Clark.

Heyns, J.A. 1978. Dogmatiek. Pretoria: N.G. Kerkboekhandel.

Hunt, A. 2005. Trinity: Nexus of the mysteries of Christian Faith. Maryknoll: Orbis.

Kärkkäinen, V-M. 2007. The Trinity: Global Perspectives. Louisville: Westminster/John Knox.

-2014. Trinity and revelation: A constructive Christian theology for the pluralistic world (Vol 2). Grand Rapids: Eerdmans.

-2015. Loving Father, Embodied Son, and Life-Giving Spirit: The Trinitarian Narrative and Liturgical Experience. Liturgy, 30(1):60-66.

LaCugna, C.M. 1986. Making the most of Trinity Sunday. Worship, 60:210-224. 
-1991. God for us: The Trinity and Christian Life. San Francisco: Harper Collins.

Letham, R. 2004. The Holy Trinity: In Scripture, history, theology and worship. Phillipsburg:

P\&R.

Leup, R.T. 1996. Knowing the name of God: A Trinitarian tapestry of grace, faith \& community. Downers Grove: Inter Varsity Press.

Lord, J.L. 2012. Pentecost and Trinity Sunday: Preaching and teaching new creation. Interpretation, 66(1):29-40.

McGrath, A. 2006. The doctrine of the Trinity: an evangelical reflection, in T. George (ed.). God the Holy Trinity: Reflections on Christian faith and practice. Grand Rapids: Baker Academic. 17-35.

Moltmann, J. 1981. The Trinity and the Kingdom, M. Kohl (tr.). San Francisco: Harper \& Row.

-1991. History and the triune God: Contributions to Trinitarian theology, J. Bowden (tr.). London: SCM Press.

-2000. Perichoresis: An Old Magic Word for a New Trinitarian Theology, in M.D. Meeks (ed.). Trinity, Community and Power: Mapping trajectories in Wesleyan Theology. Nashville: Kingswood Books. 111-125.

Olson, R.E. \& Hall, C.A. 2002. The Trinity. Grand Rapids: Wm B Eerdmans.

Pembroke, N. Renewing pastoral practice: Trinitarian perspectives on pastoral care and counselling. Aldershot: Ashgate.

Plantinga, R.J., Thompson, T.R. \& Lundberg, D. 2010. An introduction to Christian theology. Cambridge: Cambridge University Press.

Schaefer, M.M. 2010. Presence of the Trinity: Relationship or Idea? Liturgical Ministry, 19:145-156.

Schwöbel, C. 1998. God is Love: The model of love and the Trinity. Neue Zeitschrift für Systematische Theologie und Religionsphilosophie, 40:307-328. 
Shuster, M. 1999. Preaching the Trinity: A Preliminary Investigation, in S.T. Davis, D. Kendall \& G. O'Collins (eds). The Trinity: An Interdisciplinary Symposium on the Trinity. Oxford: Oxford University Press. 357-381.

Suggit. J. 1993. The simplicity of God: God as Trinity. Marshalltown: JN Suggit.

Tyson, J.R. 2005. Who is God in three Persons? A study of the Trinity. Nashville: Abingdon Press.

Venter, R. 2014. The triune God and the relational turn: Implications for reconciliation in South Africa? Unpublished paper presented at the Tutu-Jonker dialogue series on Reconciliation. 31st July, Bloemfontein.

Vincie, C. 2010. Trinity Sunday: Understanding and preaching it. Liturgical Ministry, 19:182-187

Volf, M. 1998. “The Trinity is our Social: Program": The Doctrine of the Trinity and the Shape of Social Engagement. Modern Theology, 14:403-423.

Vosloo, R.R. 2004. Identity, Otherness and the Triune God: Theological groundwork for a Christian ethic of hospitality. Journal of Theology for Southern Africa, 119:69-89.

Wadell, P.J. 2011. Sharing peace: Discipline and trust, in S. Hauerwas \& S. Wells (eds) The Blackwell Companion to Christian Ethics. Oxford: Blackwell Publishers, 344-356.

White, J.R. 1998. The Forgotten Trinity. Minneapolis: Bethany House.

Zizioulas, J.D. 1985. Being as communion: Studies in personhood and the Church, Crestwood St Vladimir's Seminary Press. 